\title{
強制変位加振による渦励振の引き込み現象
}

吉武 裕 ${ }^{* 1}$, 永代 行日出 ${ }^{* 2}$, 桑園 慎太郎 ${ }^{* 3}$, 山口 雄大 ${ }^{* 4}$, 井上 堅二朗 ${ }^{* 5}$, 田中 智大 ${ }^{* 6}$

\section{Entrainment phenomenon by forced displacement excitation in vortex induced vibration}

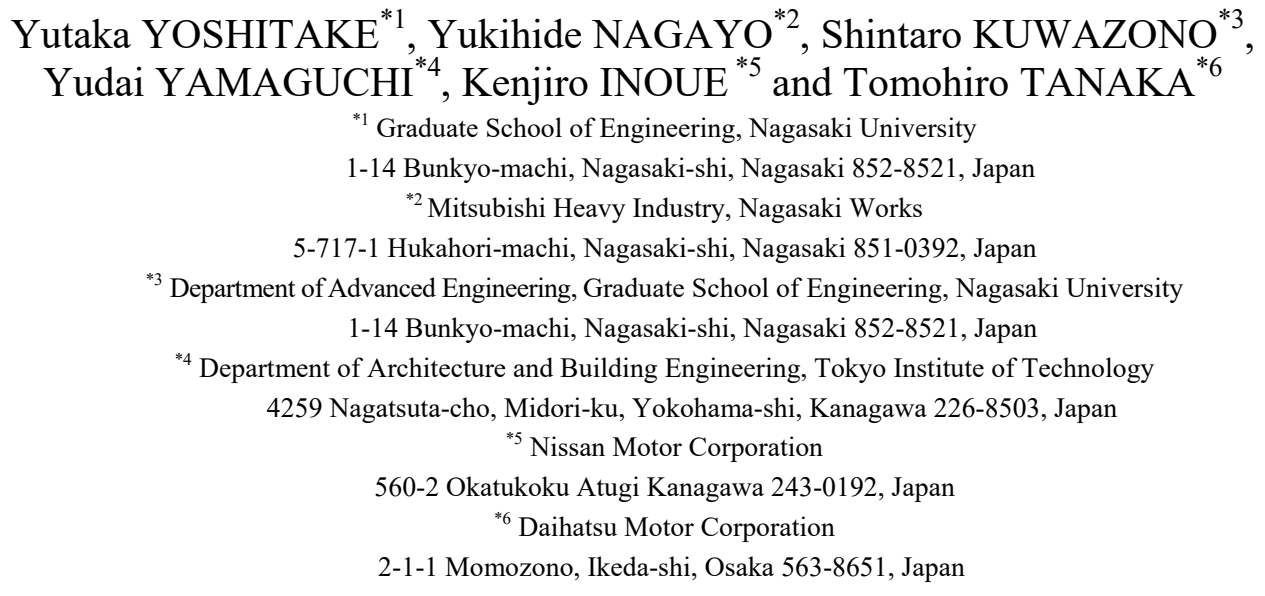

Received: 12 April 2020; Revised: 20 July 2020; Accepted: 24 August 2020

\begin{abstract}
This paper deals with the entrainment phenomenon by forced displacement excitation in vortex induced vibration of structures. This phenomenon can occur when a long-period earthquake occurs in a super high-rise structure that may have vortex induced vibration and can occur also when an offshore floating wind turbine is affected by wind and swell simultaneously. Moreover, it is important to examine this phenomenon from the viewpoint of the multi-degree-of-freedom forced self-excited system. By the experiment using wind tunnel and the numerical analysis using shooting method and ordinally numerical integration, following was made clear: (1) Entrainment phenomenon was confirmed in the excitation frequency region including the natural frequency . (2) There is the case that the entrainment region is wider at the higher wind speed than at the wind speed with the largest amplitude by vortex excitation. (3) Regarding the resonance amplitude in entrainment region, there is the case that its amplitude is slightly larger at the higher wind speed than that at the wind speed when the amplitude by the vortex excitation is the largest. (4) The largest vibration amplitude at entrainment is a value almost close to the sum of the largest amplitude at the time of only the vortex excitation and that at the time of only the forced displacement excitation. (5) The experimental results and the numerical analysis results mentioned above were almost qualitatively consistent.
\end{abstract}

Keywords: Nonlinear vibration, Vortex induced vibration, Selfexcited vibration, Forced vibration, Entrainment

\section{1. 緒 言}

近年, 国内の大都市では建物の超高層化が進むとともに, 超々高層のビルやタワーも建設されている. 例えば, 横浜ランドマークタワー, あべのハルカス, スカイツリーなどである. この傾向は今後も続くと思われる. 横浜

No.20-00145 [DOI:10.1299/transjsme.20-00145], J-STAGE Advance Publication date : 1 September, 2020

*1 正員, 長崎大学 大学院工学研究科（干852-8521 長崎県長崎市文教町 1-14）

*2 正員, 三菱重工 (株) 総合研究所（T851-0392＼cjkstart長崎県長崎市深堀町 5-717-1）

*3 学生員, 長崎大学 大学院工学研究科 総合工学専攻

*4 東京工業大学 環境・社会理工学院（†226-8503 神奈川県横浜市緑区長津田町 4259）

*5 日産自動車 (株) (†243-0192 神奈川県厚木市岡津古久 560-2)

*6 ダイハツ工業 (株) (干563-8651 大阪府池田市桃園 2-1-1)

E-mail of corresponding author: yoshitak@nagasaki-u.ac.jp 
Yoshitake, Nagayo, Kuwazono, Yamaguchi, Inoue and Tanaka,

ランドマークタワーでは，地震荷重よりも風向直角方向の渦励振等による風荷重の影響を大きく受けるという考 えから，風向直角方向の風荷重に耐えるように設計されている（山崎，1992）（三菱地所，1994）。また，渦励振 は煙突や鉄塔などの塔状構造物においても従来から問題となっている（本間他，2006）.

一方，日本では近年，直下型や海洋型の大地震の発生が危惧されており，大地震の場合，地震波そのものが長 周期化する傾向にあるだけでなく, 大都市が広がる大きな平野部では, 地盤の構造により長周期成分がさらに卓 越する. 2007 年の新潟県中越沖地震や 2011 年の東北地方太平洋沖地震においても, 関東地方では長周期のかな り周期的な地震波が観測されている（古村他，2007）(佐々木他, 2018).このような地震波の特性により，近年， 前述の超高層や塔状の構造物が地震波と共振する可能性があるということで問題となっている（赤木他，2012） (嶺脇他, 2017).

このような状況から, 超高層構造物や塔状構造物は, 風による自励振動である渦励振の発生時に大地震が起こ ると，自励振動とかなり周期的な強制加振を同時に受ける状態がおこる可能性がある．そのような場合，振動学 的には強制自励系となるが，渦励振に強制力が加わる系を強制自励系として研究した例はほとんどない．著者ら が検索した範囲では，風洞ではなくウォータートンネルを用いた研究で，外力による引き込みを利用した渦の制 御に関する実験的研究（飯吉他，2012）があるのみである. 国内で大地震の発生が迫っている現在，早急な研究 とそれに基づく対応が望まれる.

渦励振を行う系に強制力が作用し, 強制自励系として扱うべき例として, 以下に述べるような浮体式洋上風車 における波やう衫りと渦励振の同時作用が考えられる. 諸外国では, 洋上風車は海底固定式のものが商業運転さ れているのに対して，遠浅の海岸線が少ない日本では浮体式とせざるを得ず，長崎県五島沖にのみ商業運転中の 浮体式洋上風車がある.この浮体式洋上風車は 2016 年に実証実験が終了した後, 商業運転に移行したものである が, 今後, 浮体式洋上風車を国内に広く普及させていくためにはさらに様々な検討が必要である. すなわち, 洋 上の風環境下の風車は渦励振の可能性があり（大塚他，2004），また，波やうねりによる強制変位型の外力も作用 する (NEDO, 2018).よって, 強制自励系として振動する可能性があり, その検討が必要である.

強制自励系に関しては古くから研究が行われ, 強制力の振動数が自励振動の振動数に近いときに系の振動応答 から自励振動の振動数成分が消え失せ，強制振動の振動数のみで振動する，いわゆる引き込み現象が生ずること が知られている．強制自励系における引き込み現象の研究は, Van der Pol の方程式に強制力が作用するもの

(Hayashi, 1964)，乾燥摩擦と強制力が作用する系（Shaw and Shaw, 1991）（中井，秋山，1993），引き込みを利用 した振子の運動制御（梶原他，2001）など多くの研究が行われてきた．著者らも時間遅れによる自励振動系に強 制力が作用寸る場合（吉武他, 1983）や摩擦振動系に強制力が作用寸る場合の引き込み現象やカオス（吉武他, 1995) を研究してきた.これら従来研究が行われてきた強制自励系と強制変位外力が作用寸る渦励振系の違いは, 前者の振動解析モデルが 1 自由度系であることに対して, 後者の振動解析モデルは, 例えば, Iwan の渦励振モデ ル（Iwan and Blevins, 1974）のように，流体に関する 1 自由度の系と構造物に関する 1 自由度の系が連成した 2 自由度振動系であることである，それゆえ，前者の場合，例えば，Van der Pol の式では式中に含まれる唯一のパ ラメータの值に拘らず自励振動の振幅は約 2 であるが, 後者の場合, 風速により自励振動の振幅が異なり, また, 前者の場合, 全ての系で振動数に関連する情報は系の固有振動数 1 つであるのに対し, 後者の場合, 渦の発生振 動数も加えて $2 つ$ 存在するなど, 両者は自励振動系そのものの構成が異なるゆえに, 後者の強制自励系としての 挙動を調べることは意義があることである.

なお，振動する物体の周りに発生するカルマン渦の挙動と流体中の物体に作用する力に関する多くの研究があ り, そこでは流れの中で円柱を一定振幅・振動数で振動させたときの渦列の発生パターンの違いや流体力が調べ られているものの（Williamson and Roshko, 1988）（岡島, 2000）（松本他，2008）（Atluri et al., 2009）, これらの研 究は流体中の構造物の振動挙動を強制自励振動系として調べたものではない.

このような状況に鑑み, 本研究は構造物の而風・耐震, 洋上風車の安全性, および多自由度の強制自励系の観 点から, 強制変位による渦励振系の引き込み現象の特徵を明らかにすることを目的とする基礎的な研究である.

\section{2. 実 験}

\section{$2 \cdot 1$ 実験装置}


実験装置の概略を図 1 に示す，風洞外壁の上部と下部にそれぞれ同じ強制変位加振用のボールねじを用いた高 精度アクチュエータを設置し，各アクチュエータには 2 本の板ばねの一端を接続している，板ばねの他端には風 洞内の円筒の上下端の端板が接続されている.この 2 個のアクチュエータを同期駆動し, 上下の板ばね固定端を 同位相で変位加振することにより円筒を並進運動させている（図 1 では面外方向に相当する）。パソコンで 2 個 のアクチュエータを制御することにより, 板バネ固定部において所定の強制変位の振動数と振幅を実現している. この強制変位加振は，構造物に作用する地震や波浪による強制変位加振に相当寸る. 風洞の断面（風の流れと垂 直な図 1 の面外方向）のサイズは縦 400mm，横 300mm である．板ばねはアルミ製で，長さ $237 \mathrm{~mm}$ ，幅 $9 \mathrm{~mm}$ ， 厚さ $1.5 \mathrm{~mm}$ である. 円筒はアルミ製で直径 $45 \mathrm{~mm}$ ，長さ $350 \mathrm{~mm}$ ，厚さ $0.2 \mathrm{~mm}$ である．板バネと円筒からなる主 系の質量は $365.7 \mathrm{~g}$ である. 上下の板ばね固定端の加振変位と円筒の変位はレーザー変位計を用いて測定した. 八 ンマリング試験の結果, 固有振動数は $7.00 \mathrm{~Hz}$ ，減衰比は 0.0055 であった.

\section{$2 \cdot 2$ 風速応答}

図 2 に強制変位加振を行わないときの風速応答曲線を示す. 図の横軸は風速 $U$, 縦軸は円筒の変位振幅 $A_{V}$ であ る. 図から風速が約 $1.50 \mathrm{~m} / \mathrm{s}$ から $1.70 \mathrm{~m} / \mathrm{s}$ の範囲の振幅が大きく, 渦励振が発生している領域である. 円筒の変位

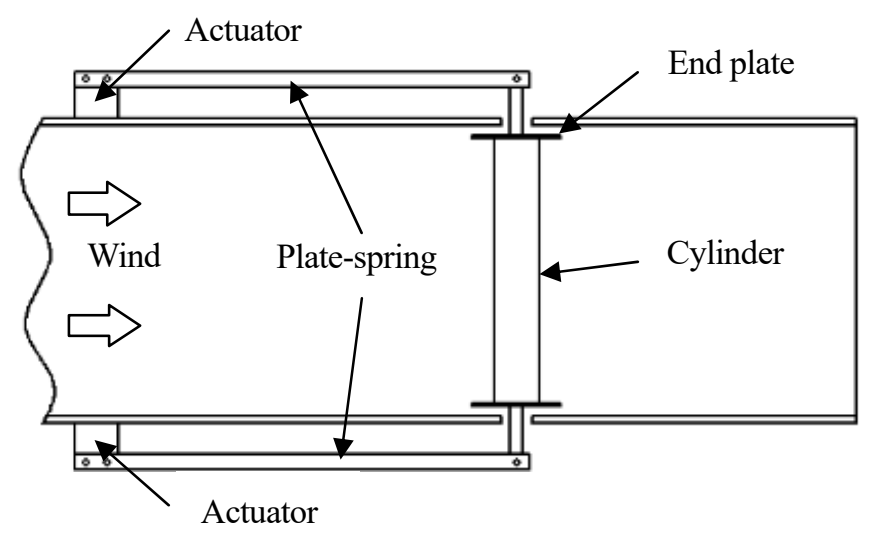

Fig. 1 Experimental apparatus.

To give displacement excitation, two actuators are installed on the upper and lower parts of the wind tunnel outer walls, and one ends of the upper leaf springs and those of lower ones are connected to the upper actuator and lower one respectively. A cylinder is connected to the other ends of the leaf springs.

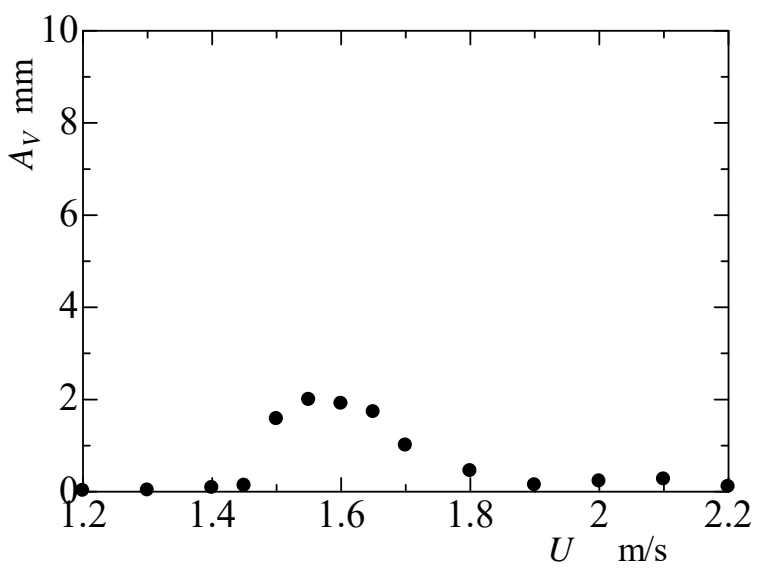

Fig.2 Wind response curve (Without forced displacement excitation).

The amplitude of the cylinder is large when the wind speed is in the range of about $1.50 \mathrm{~m} / \mathrm{s}$ to $1.70 \mathrm{~m} / \mathrm{s}$. Vortex induced excitation occurs in this wind speed region. 


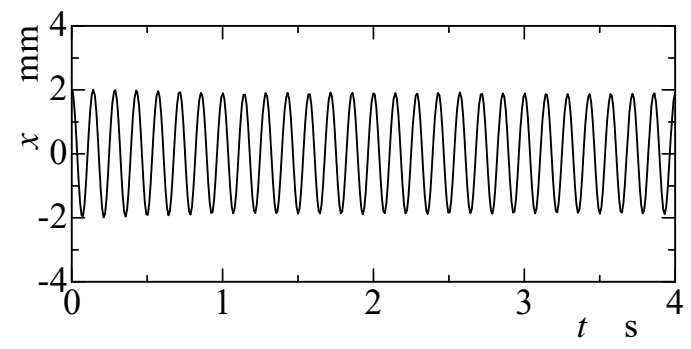

(a) $U=1.55 \mathrm{~m} / \mathrm{s}$

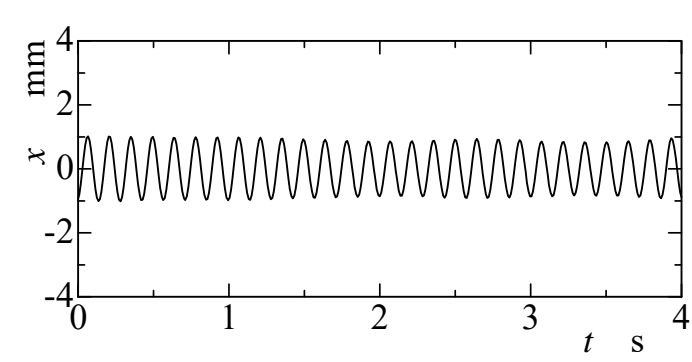

(b) $U=1.70 \mathrm{~m} / \mathrm{s}$

Fig.3 Waveforms.

From the figure, it can be seen that steady vibration with almost constant amplitude is occurring. The amplitude varies depending on the wind speed in the lock-in area.

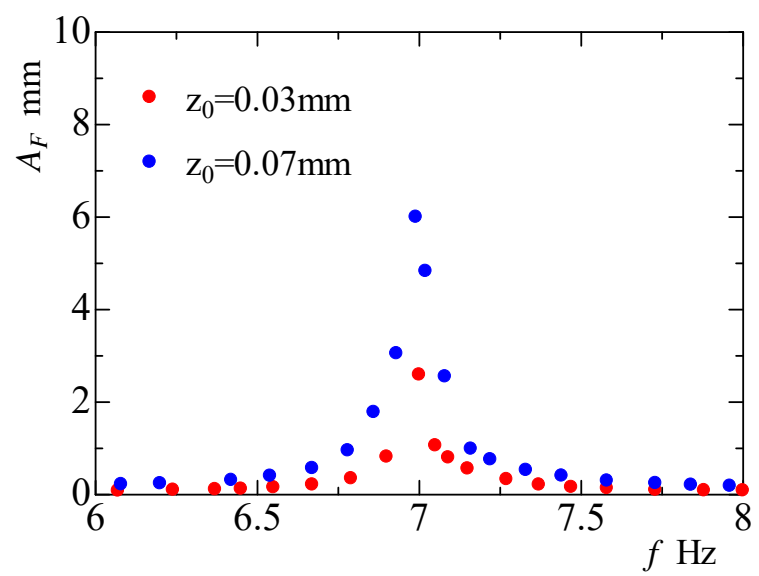

Fig.4 Resonance curve.

This shows a typical resonance curve of a single-degree-of-freedom system. The resonance curve is slightly inclined toward the lower frequency side and shows a very small soft-spring nonlinearity.

振幅は風速 $1.55 \mathrm{~m} / \mathrm{s}$ の時に最大值の約 $2.0 \mathrm{~mm}$ となっている. 図 3 に代表的な変位波形を示寸. 横軸は時間 $t$, 縦 軸は変位 $x$ である. 図 3(a)は風速 $1.55 \mathrm{~m} / \mathrm{s}$ のときの変位波形である. 図からほぼ一定振幅の定常的な振動を行って いることがわかる. 図3(b)は風速 $1.70 \mathrm{~m} / \mathrm{s}$ のときの変位波形である. 図からこの風速の時もほぼ一定振幅の定常 的な振動であるが，図 3(a)の風速 $1.55 \mathrm{~m} / \mathrm{s}$ のときのほぼ半分の約 $1.0 \mathrm{~mm}$ の振幅であることがわかる. 振動数はい ずれも $6.99 \mathrm{~Hz}$ である. 渦励振は, Van der Pol の式の解と異なり, 系のパラメータの 1 つである風速により自励振 動の振幅が異なるのが特徴である.

\section{$2 \cdot 3$ 共振曲線}

図 4 に風力を作用させない状態で, 強制変位加振のみ行った時の共振曲線を示す. 図の横軸は振動数 $f$, 縦軸 は円筒の変位振幅 $A_{F}$ である. 図の赤丸印は強制変位振幅 $z_{0}$ が $0.03 \mathrm{~mm}$, 青丸印は強制変位振幅 $z_{0}$ が $0.07 \mathrm{~mm}$ の場 合の円筒の変位振幅を示している. それぞれの共振振幅は約 $2.6 \mathrm{~mm}$ と約 $6.0 \mathrm{~mm}$ である. 1 自由度系の典型的な共 振曲線であるが，共振曲線はごくわずかに低振動数側に傾き，ごく小さな非線形性を示してことがわかる．この 理由については不明である．なお，アクチュエータに固定している板ばね端部の振動変位を常時高精度のレーザ 一変位計で監視しているが，振動数によっては，強制変位振幅 $z_{0}$ に最大で $5 \%$ 程度の誤差が含まれることがわか った.これは，アクチュエータで設定可能な移動距離と移動速度の分解能による.

\section{$2 \cdot 4$ 渦励振時の強制変位加振}


Yoshitake, Nagayo, Kuwazono, Yamaguchi, Inoue and Tanaka,

Transactions of the JSME (in Japanese), Vol.86, No.889 (2020)

ここでは渦励振発生時に強制変位加振を行ったときの実験結果を示寸.このとき, 系は強制自励系となる. 図 5 に加振振幅 $z_{0}$ が $0.03 \mathrm{~mm}$ の時の共振曲線を示寸. 図 $5(\mathrm{a})$ は風速を $U=1.55 \mathrm{~m} / \mathrm{s}$ に固定した時の共振曲線であり, 図 5(b)は風速を $U=1.70 \mathrm{~m} / \mathrm{s}$ に固定した時の共振曲線である. 図の横軸は強制変位の振動数 $f$, 縦軸は円筒の変位 振幅 $A_{V F}$ である. 図の黒丸印は振動数成分が強制変位加振振動数のみとなり引き込み現象が発生したときの定常 変位振幅を表し, 白丸印は渦励振の振動数と強制変位加振振動数が共存するうなり振動が発生した時の平均変位 振幅を示している. 図 6(a) と図 6 (b) に例として, 加振振幅 $z_{0}=0.03 \mathrm{~mm}$, 風速 $U=1.70 \mathrm{~m} / \mathrm{s}$ で, 加振振動数 $f=7.00 \mathrm{~Hz}$ と $f=7.47 \mathrm{~Hz}$ の時の変位波形をそれぞれ示している. 図 6(a) の波形が引き込み振動，図 6(b)の波形がう なり振動である. それぞれ振動数 $7.00 \mathrm{~Hz}$ の周期的であるものと, 主に振動数 $6.97 \mathrm{~Hz}$ と $7.47 \mathrm{~Hz}$ からなるうなりと なっている.

図 5(a) と図 5 (b)の共振曲線を比較すると，いずれも固有振動数 $7.0 \mathrm{~Hz}$ 付近で引き込み領域が存在するが，その 引き込み領域の広さは，図 2, 3 で示した渦励振振幅が最大の風速である $U=1.55 \mathrm{~m} / \mathrm{s}$ の時よりも少し高い風速で ある $U=1.70 \mathrm{~m} / \mathrm{s}$ の時の方が少し広いことがわかる. 振幅の最大值は図 $5(\mathrm{a})$ と図 $5(\mathrm{~b})$ で差は小さいが, $U=1.55 \mathrm{~m} / \mathrm{s}$ の時は約 $4.4 \mathrm{~mm}, U=1.70 \mathrm{~m} / \mathrm{s}$ の時は約 $4.5 \mathrm{~mm}$ である. 図の白丸で示したうなり振動時の平均振幅は, 強制加振し ない渦励振のみの時の振幅が大きな風速 $U=1.55 \mathrm{~m} / \mathrm{s}$ の時の方が平均振幅は大きいことがわかる.

図 7 に加振振幅 $z_{0}$ が $0.07 \mathrm{~mm}$ の時の共振曲線を示す. 図 7(a) は風速を $U=1.55 \mathrm{~m} / \mathrm{s}$ に固定した時の共振曲線で あり, 図 7(b)は風速を $U=1.70 \mathrm{~m} / \mathrm{s}$ に固定した時の共振曲線である. 図の横軸と縦軸の定義, 黒丸印と白丸印の定 義は図 5 と同様である. 図 5 と図 7 を比較すると, まず, 加振振幅が大きい図 7 の方が引き込み領域が広いこと

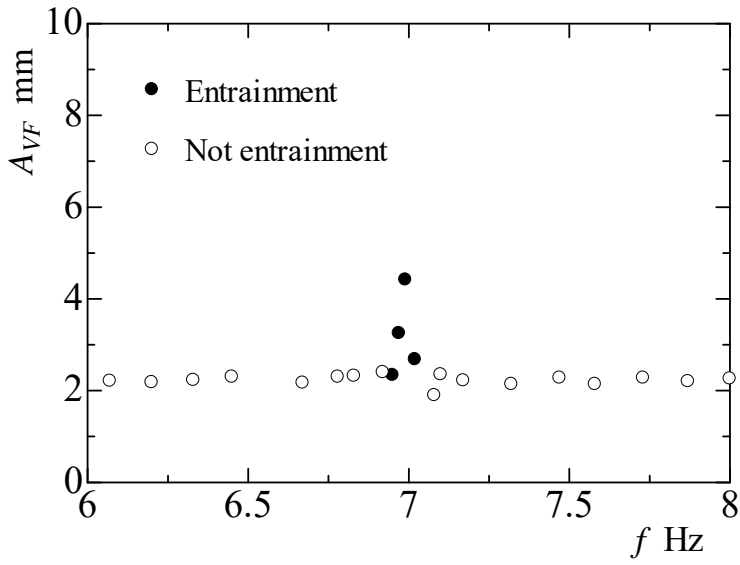

(a) $U=1.55 \mathrm{~m} / \mathrm{s}$

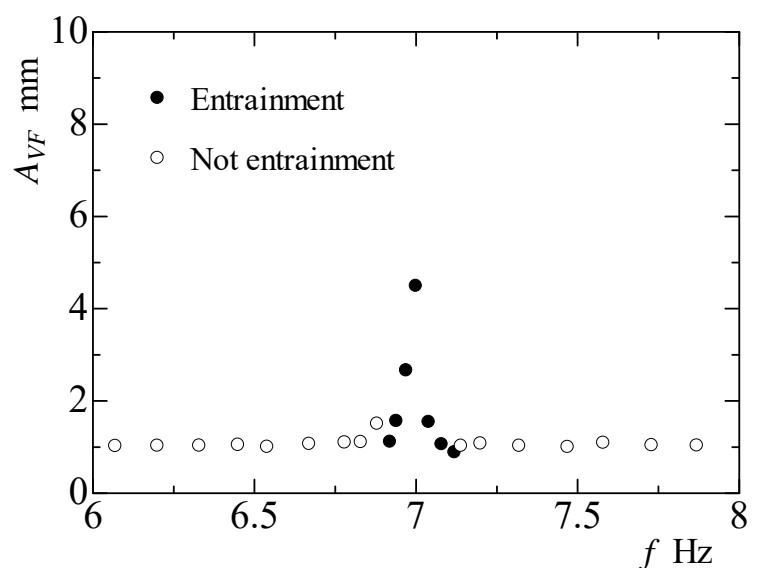

(b) $U=1.70 \mathrm{~m} / \mathrm{s}$

Fig. 5 Resonance curve $\left(z_{0}=0.03 \mathrm{~mm}\right)$.

It can be seen that the entrainment region is slightly wider when the vortex excitation amplitude is small at $U=1.70 \mathrm{~m} / \mathrm{s}$ than when the vortex excitation amplitude is large at $U=1.55 \mathrm{~m} / \mathrm{s}$. The maximum amplitude is also slightly larger in the former than in the latter.

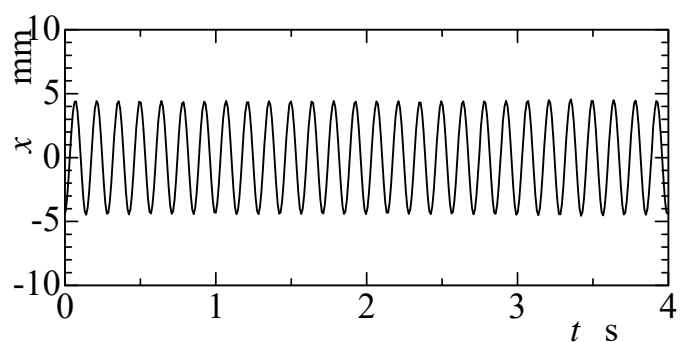

(a) $f=7.00 \mathrm{~Hz}$

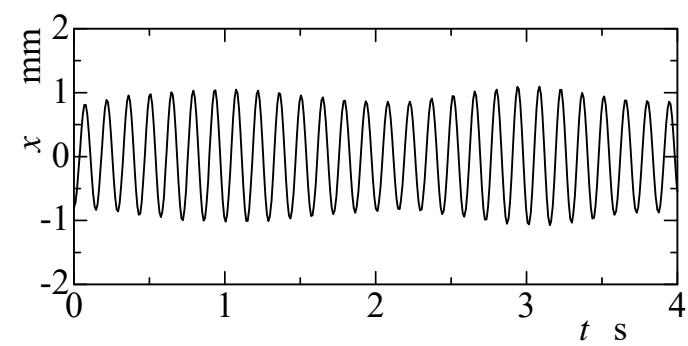

(b) $f=7.47 \mathrm{~Hz}$

Fig.6 Waveforms $\left(z_{0}=0.03 \mathrm{~mm}, U=1.70 \mathrm{~m} / \mathrm{s}\right)$.

The waveform in fig. 6 (a) is that of the entrainment vibration, and fig. 6 (b) is the waveform of the beat vibration. Both can be clearly distinguished by waveforms. 


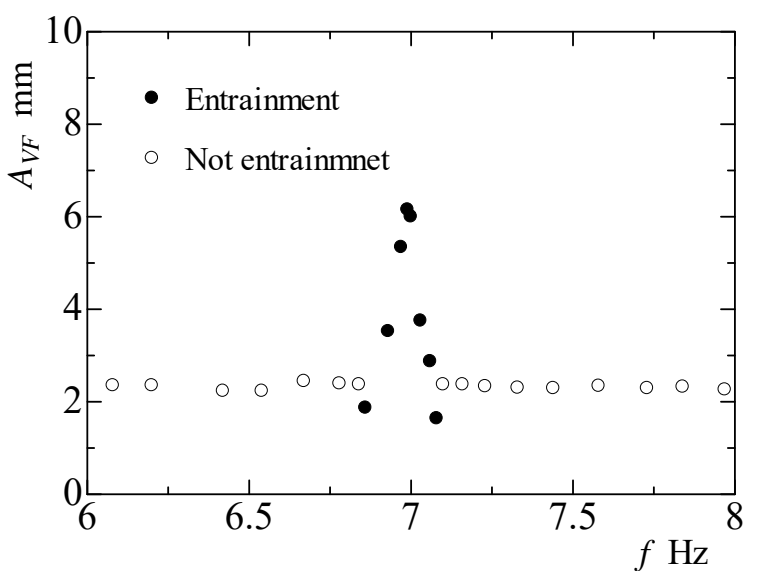

(a) $U=1.55 \mathrm{~m} / \mathrm{s}$

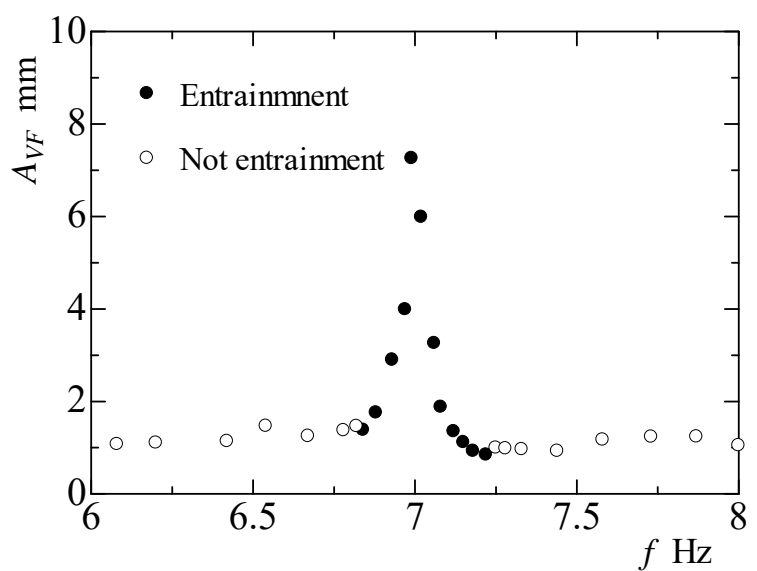

(b) $U=1.70 \mathrm{~m} / \mathrm{s}$

Fig.7 Resonance curve $\left(z_{0}=0.07 \mathrm{~mm}\right)$.

Comparing Fig. 5 with Fig.7, it can be seen that Fig.7 in the case of larger excitation amplitude has a wider entrainment region. This is the same feature as a general forced self-excited system. Also, it can be seen that the amplitude of the resonance amplitude does not reach twice even if the excitation amplitude becomes twice or more. Regarding the resonance amplitude in entrainment region, it is slightly larger at the higher wind speed than that at the wind speed when the amplitude by the vortex excitation is the largest.

がわかる．これは一般的な強制自励系と同じ特徵である。また，共振点の振幅は図 7 で加振振幅が 2 倍以上にな っても図 5 の場合の 2 倍には達していないことがわかる.これは強制自励系ゆえであり, 強制力が作用する Van der Pol 方程式の場合（Hayashi, 1964）と同様である.

渦励振と強制変位加振が共存する場合の共振振幅は，風速 $U=1.55 \mathrm{~m} / \mathrm{s}$ のときは，加振振幅 $z_{0}$ が $0.03 \mathrm{~mm}$ のとき は図 5(a)から約 $4.4 \mathrm{~mm}$, 加振振幅 $z_{0}$ が $0.07 \mathrm{~mm}$ のときは図 7(a)から約 $6.2 \mathrm{~mm}$ である. これに対して, 風速 $U=1.70 \mathrm{~m} / \mathrm{s}$ のときの共振振幅は，加振振幅 $z_{0}$ が $0.03 \mathrm{~mm}$ のときは図 5(b)から約 $4.5 \mathrm{~mm}$ ，加振振幅が $0.07 \mathrm{~mm}$ のときは図 7(b) から約 $7.3 \mathrm{~mm}$ である.このことから，実験を行った範囲では，強制自励振動時の共振振幅は，渦励振のみの時の 振幅が最大の時の風速よりも少し高い風速の方が大きいことがわかった。これは円柱を強制加振した時の励振揚 力の最大值が高風速側にずれるという実験結果（田中，高原，1970）と対応している.

\section{3. 解析モデルと運動方程式}

\section{$3 \cdot 1$ Iwanの渦励振モデル}

前章の実験で示した渦励振を行う系を強制変位加振した強制自励系の実験結果を数值計算から検証す る. 渦励振現象を表す低次元のモデルはいくつかあるが，ここでは著者らの以前の研究（吉武他，2006） でも用いて実験結果と数值計算結果が定性的に一致した Iwan の渦励振モデル（Iwan and Blevins, 1974）を 用いて数值計算を行う.

カルマン渦による円筒の振動を図 8 に示す Iwan の渦励振モデルに従って簡単に説明する. 図 8 の検査 面内における力の釣り合いは次式のようになる.

$$
\dot{J}_{x}=P_{x}-S_{x}-F_{z}
$$

ここに， $J_{x}$ は検査面内の流体の持つ流れと直交する $x$ 方向の運動量であり， $P_{x}$ は流体に作用する上向き の力で面III IVに作用する圧力と面I IIに作用する圧力の差に起因する． $F_{z}$ は円筒から流体に作用する力 (円筒に作用する流体力の反力) である． $S_{x}$ は面I IVから流入する運動量と面II IIIから流出する運動量の増 加率の差であるが, 主に渦放出による運動量変化を表す。これらは次のようになる。

$$
J_{x}=b_{0} \rho D^{2} \dot{u}, \quad P_{x}=0, \quad F_{z}=b_{4} \rho D U(\dot{u}-\dot{x}),
$$




$$
\begin{aligned}
& S_{x}=K \rho U \omega_{s} D u-b_{1} \rho U D \dot{u}+\left(b_{2} \rho D / U\right) \dot{u}^{3}, \\
& \omega_{s}=2 \pi S_{t} U / D
\end{aligned}
$$

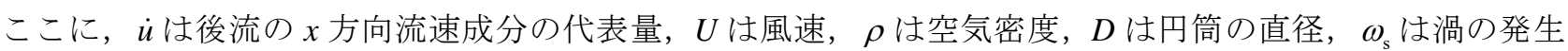

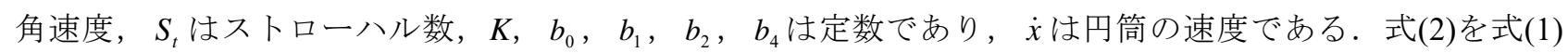
に代入すると次式を得る。

$$
b_{0} \rho D^{2} \ddot{u}-b_{1} \rho U D \dot{u}+\frac{b_{2} \rho D}{U} \dot{u}^{3}+K \rho U \omega_{s} D u=-b_{4} \rho D U(\dot{u}-\dot{x})
$$

一方，長さ $L$ の円筒には流体力 $F_{z} L$ が作用する.

\section{$3 \cdot 2$ 解析モデル}

本論文では, 前述のように構造物が渦励振されるだけでなく, 同時に強制変位加振される場合を考える. 解析モデルを図 9 に示している. 構造物を円筒形状とし, この円筒が粘性減衰効果をもつ弾性体で支持さ れ, その支持部が変位 $z$ で強制変位するとき, 円筒には支持部からの外力 $c(\dot{z}-\dot{x})+k(z-x)$ が作用する. 前述の流体力 $F_{z} L$ も考慮すると, 円筒の運動方程式は次式で表される.

$$
m \ddot{x}+c \dot{X}+k x=c \dot{Z}+k z+b_{4} \rho D U L(\dot{u}-\dot{x})
$$

ここに, $m, c, k$ はそれぞれ系の質量, 粘性減衰係数, およびばね定数である. また, 強制変位は次式 の調和加振とする.

$$
z=z_{0} \cos \omega t
$$

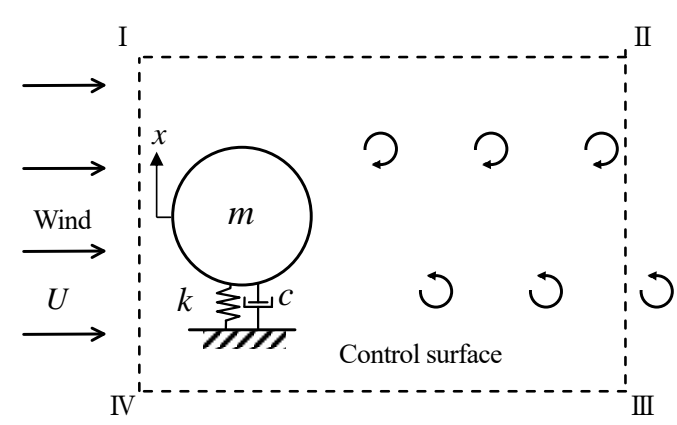

Fig.8 Iwan's model of vortex induced vibration.

Iwan proposed the vortex induced vibration model expressed by equations (1) and (2) based on the momentum, force, and velocity of the fluid in the inspection plane.

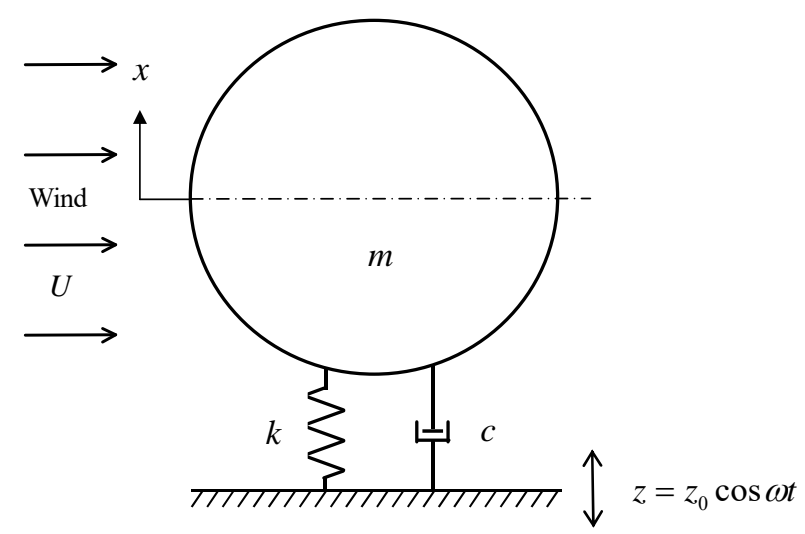

Fig.9 Analytical model of vibration system.

The cylinder is supported by an elastic body having a viscous damping effect, and the forced displacement $z$ is given to the elastic body. 
Yoshitake, Nagayo, Kuwazono, Yamaguchi, Inoue and Tanaka,

Transactions of the JSME (in Japanese), Vol.86, No.889 (2020)

緒言で述べたように，Van der Pol の式に強制力が作用する強制自励系は 1 自由度系であるが，Iwan の渦励振モデ ルを用いた強制自励系は式(3)と(4)からなる 2 自由度系となる.

\section{4. 数値解析結果}

数值解析では，渦励振，および，渦励振と強制変位加振同時作用時の引き込み振動は周期解であるので，シュ 一ティング法を用いて求めた．そのときの数值積分は，ルンゲ・クッタ・ギル法を用い， 1 周期の刻み数は 2048 とした．渦励振と強制変位加振同時作用時のうなり振動の解は長時間数值積分することにより求めた．なお，主 系のパラメータ值として，2 章で述べた質量 $m=0.3657 \mathrm{~kg}$ とハンマリング等で得られた值から， $c=0.1769 \mathrm{Ns} / \mathrm{m}$, $k=707.4 \mathrm{~N} / \mathrm{m}$ を用いた。

\section{$4 \cdot 1$ 風速応答}

図 10 に風速応答曲線を示寸. 図の横軸は風速 $U$, 縦軸は円筒の変位振幅 $A_{V}$ である. 図 11 に代表的な変位波形 を示す．図 11(a)と図 11(b)はそれぞれ風速 $1.60 \mathrm{~m} / \mathrm{s}$ と 1.70 m/s のときの変位波形である. このとき用いたパラメー タの值は以下のとおりである.

$$
S_{t}=0.203, \quad K=0.529, \quad b_{0}=0.415, \quad b_{1}=1.04, \quad b_{2}=1.15, \quad b_{4}=1.11
$$

図 10 から Iwan の渦励振モデルの各パラメータを試行錯誤によりこのように有効数字 3 桁で選ぶことにより渦 励振が発生する風速領域（ロックイン領域）を図 2 の実験結果に近い值で表現できていることがわかる．また，

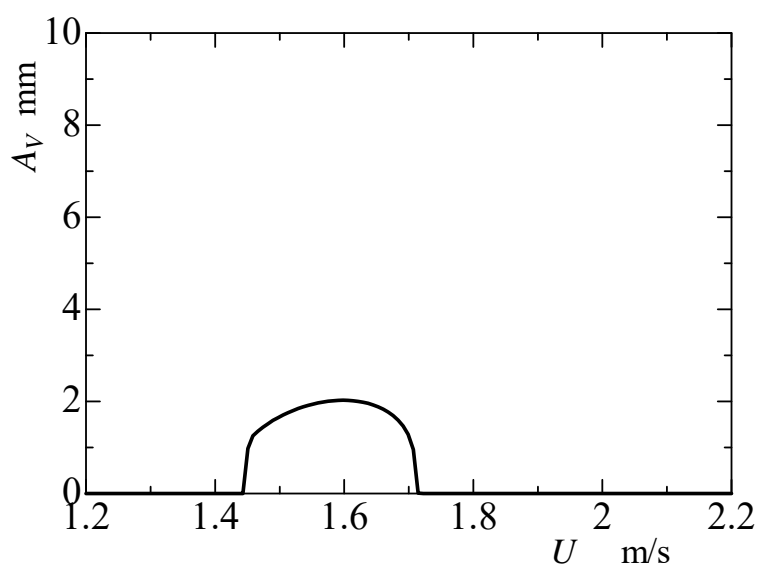

Fig.10 Wind response curve (Numerical calculation).

The lock-in region and the amplitude obtained by using the Iwan's vortex induced vibration model almost approximate the experimental results of Fig.2.

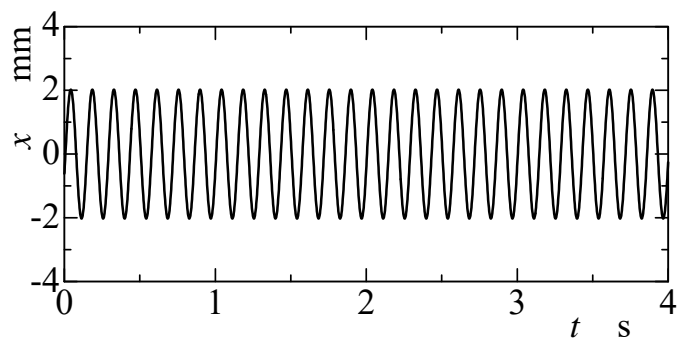

(a) $U=1.60 \mathrm{~m} / \mathrm{s}$

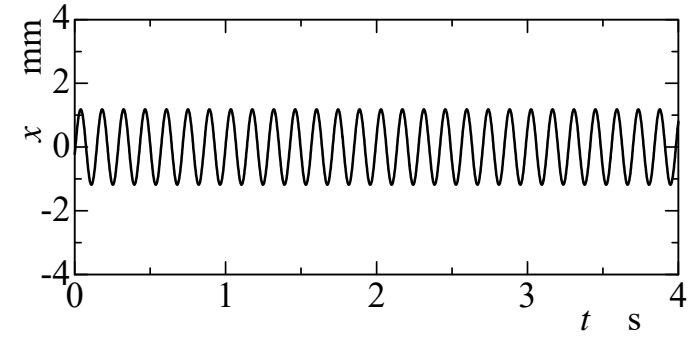

(b) $U=1.70 \mathrm{~m} / \mathrm{s}$

Fig.11 Waveforms (Numerical calculation).

Steady vibrations with constant amplitudes are obtained. In the numerical calculation using Iwan's vortex induced vibration model, the wind speed dependence of the amplitude in the lock-in region was confirmed as well as the experimental results. 
図 11 から一定振幅の定常的な振動の解が得られていること, 実験結果と同様に渦励振時の振幅は風速により異な ることがわかる．振幅の最大值は実験より少し大きな風速 $U=1.60 \mathrm{~m} / \mathrm{s}$ のときの $2.02 \mathrm{~mm}$ であり，風速 $U=1.70 \mathrm{~m} / \mathrm{s}$ のときの振幅は $1.18 \mathrm{~mm}$ と実験結果より少し大きい值となった．振動数は前者が $7.01 \mathrm{~Hz}$, 後者が $7.03 \mathrm{~Hz}$ である.

\section{$4 \cdot 2$ 共振曲線}

風力を作用させずに強制変位加振のみ作用させる時の共振曲線は単純な 1 自由度線形振動系の共振曲線になる ので，共振曲線を示すことは省略するが，強制変位振幅 $z_{0}$ が $0.03 \mathrm{~mm}$ と $0.07 \mathrm{~mm}$ の場合の共振振幅はそれぞれ $2.73 \mathrm{~mm}$ と $6.36 \mathrm{~mm}$ と実験值のそれぞれ $2.6 \mathrm{~mm}$ と $6.0 \mathrm{~mm}$ より少し大きな值となった. 減衰比に若干の誤差がある か, あるいは実験の振動数の分解能による誤差と考えられる.

\section{$4 \cdot 3$ 渦励振時の強制変位加振}

この節では, 渦励振発生時に強制変位加振を行ったときの数值計算結果を示す. Iwan の渦励振モデルのパラメ 一夕值は渦励振のみのときの数值計算で用いた值をそのまま用いている.

図 12 は加振振幅 $z_{0}$ が $0.03 \mathrm{~mm}$ の時の共振曲線である. 図 $12(\mathrm{a})$ は風速を $U=1.60 \mathrm{~m} / \mathrm{s}$ に固定した時の共振曲線 であり, 図 12(b)は風速を $U=1.70 \mathrm{~m} / \mathrm{s}$ に固定した時の共振曲線である. 図の横軸 $f$ と縦軸 $A_{V F}$ の定義は図 5 の実 験結果と同じである. 図の実線は引き込みの解の変位振幅, 破線はうなり振動の平均変位振幅を示している. 図 13(a) と図 13(b)には加振振幅 $z_{0}=0.03 \mathrm{~mm}$, 風速 $U=1.70 \mathrm{~m} / \mathrm{s}$ とし, 加振振動数をそれぞれ $f=7.00 \mathrm{~Hz}$ と $f=7.47 \mathrm{~Hz}$

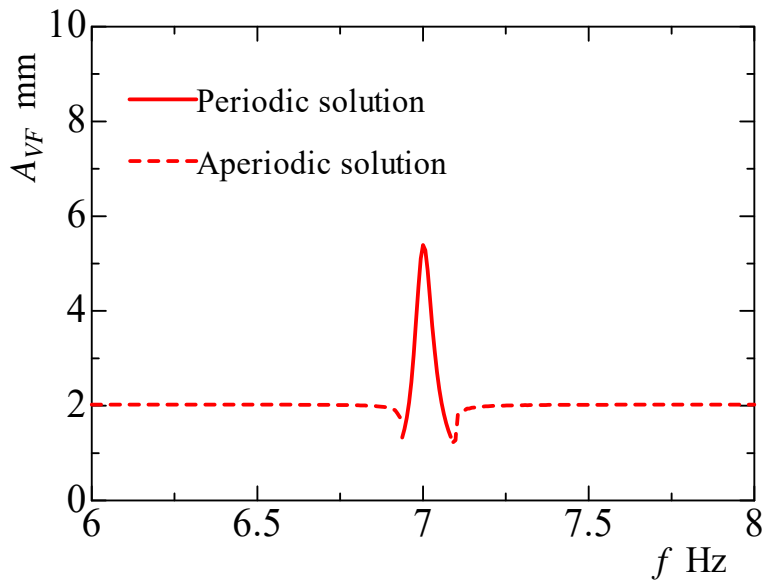

(a) $U=1.60 \mathrm{~m} / \mathrm{s}$

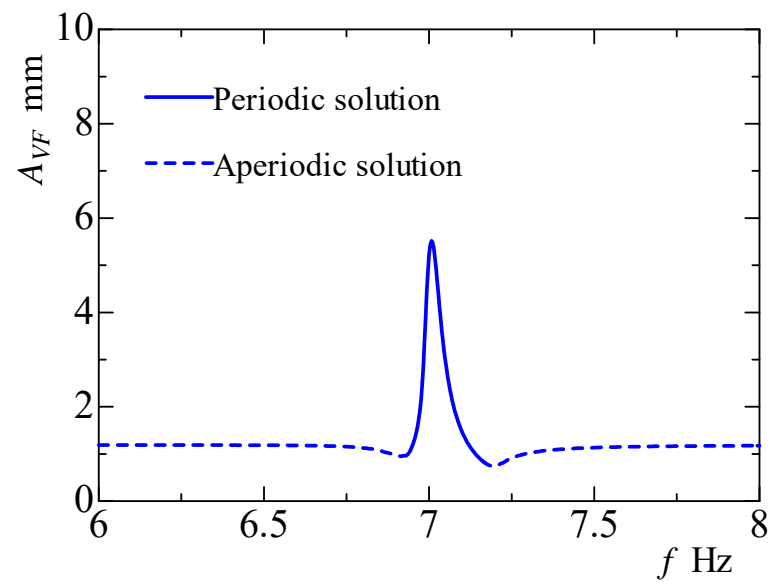

(b) $U=1.70 \mathrm{~m} / \mathrm{s}$

Fig.12 Resonance curve (Numerical calculation, $z_{0}=0.03 \mathrm{~mm}$ ).

It can be seen that the entrainment region is wider when the vortex excitation amplitude is small at $U=1.70 \mathrm{~m} / \mathrm{s}$ than when the vortex excitation amplitude is large at $U=1.60 \mathrm{~m} / \mathrm{s}$. The maximum amplitude is also slightly larger in the former than in the latter. These characteristics are the same as the experimental results.

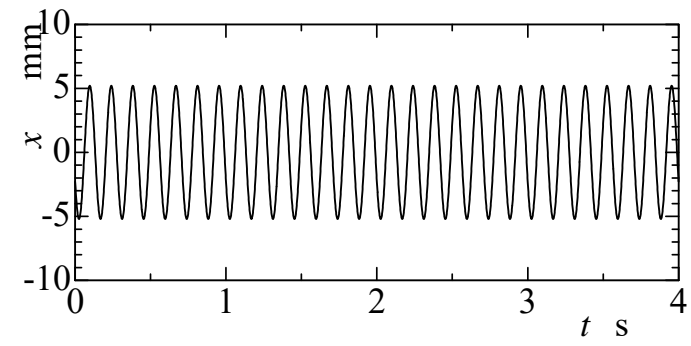

(a) $f=7.00 \mathrm{~Hz}$

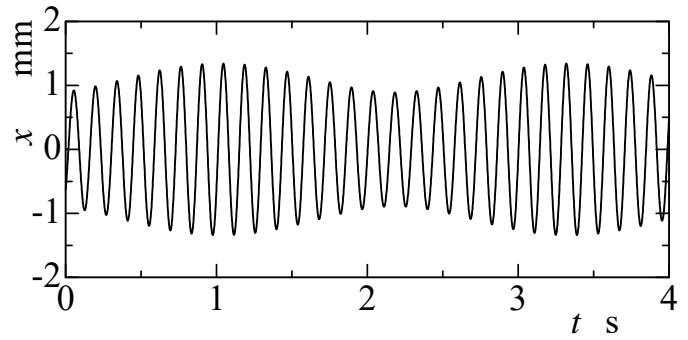

(b) $f=7.47 \mathrm{~Hz}$

Fig. 13 Wave forms (Numerical calculation, $z_{0}=0.03 \mathrm{~mm}, U=1.70 \mathrm{~m} / \mathrm{s}$ ).

The waveforms of the entrainment vibration and the almost periodic vibration like those in the experiment are obtained. 
Yoshitake, Nagayo, Kuwazono, Yamaguchi, Inoue and Tanaka,

Transactions of the JSME (in Japanese), Vol.86, No.889 (2020)

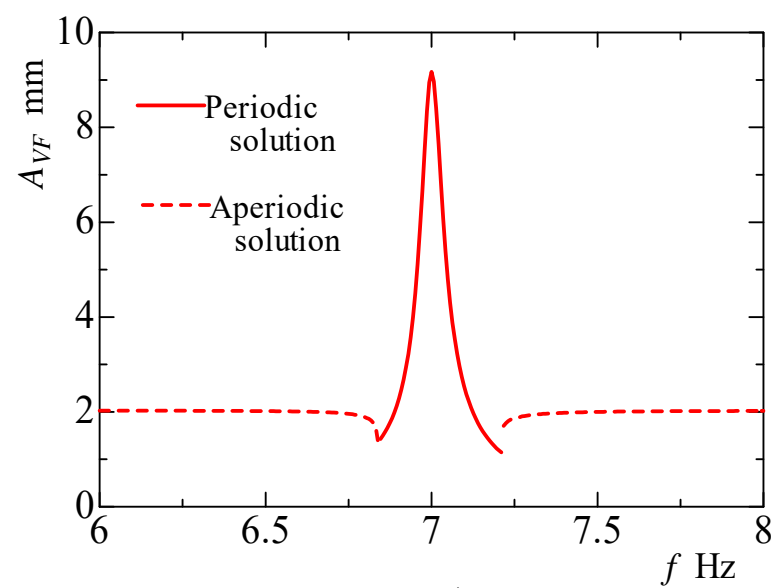

(a) $U=1.60 \mathrm{~m} / \mathrm{s}$

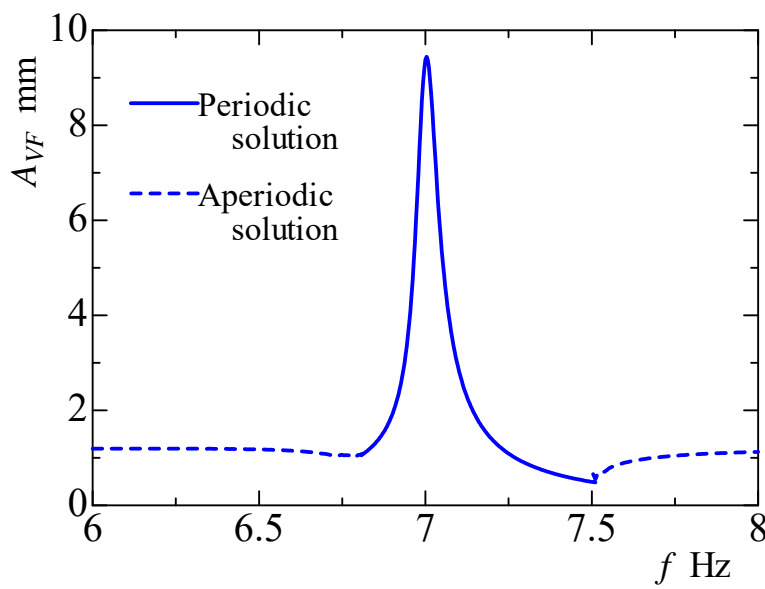

(b) $U=1.70 \mathrm{~m} / \mathrm{s}$

Fig.14 Resonance curve (Numerical calculation, $z_{0}=0.07 \mathrm{~mm}$ ).

When the wind speed is $1.70 \mathrm{~m} / \mathrm{s}$, the maximum amplitude is larger and the entrainment region is wider than when the wind speed is $1.60 \mathrm{~m} / \mathrm{s}$. Comparing fig. 12 and fig. 14 , it can be seen that fig. 14 having larger excitation amplitude has a wider entrainment region.

とした時の振動波形を示している. 実験と同様に引き込み振動とうなり振動の波形となっている. 図 12(a) と図 12(b)の共振曲線を比較すると, 図 5 の実験結果と同様にいずれも固有振動数 $7.00 \mathrm{~Hz}$ 付近で引き込 み領域が存在し，その引き込み領域の広さは，渦励振振幅が最大となる風速である $U=1.60 \mathrm{~m} / \mathrm{s}$ の場合より高い風 速である $U=1.70 \mathrm{~m} / \mathrm{s}$ の場合の方が広いことがわかる．振幅の最大值は，図 $12(\mathrm{a})$ の $U=1.60 \mathrm{~m} / \mathrm{s}$ の場合 $5.39 \mathrm{~mm}$, 図 12(b)の $U=1.70 \mathrm{~m} / \mathrm{s}$ の場合 $5.52 \mathrm{~mm}$ であり, 渦励振振幅が最大となる風速である $U=1.60 \mathrm{~m} / \mathrm{s}$ の場合より高い風速 である $U=1.70 \mathrm{~m} / \mathrm{s}$ の場合の方が引き込久時の共振振幅が少し大きいことがわかる.

図 14 に加振振幅 $z_{0}$ が $0.07 \mathrm{~mm}$ の時の共振曲線を示す. 図 $14(\mathrm{a})$ は風速を $U=1.60 \mathrm{~m} / \mathrm{s}$ に固定した時の共振曲線 であり, 図 14(b)は風速を $U=1.70 \mathrm{~m} / \mathrm{s}$ に固定した時の共振曲線である. 図の横軸と縦軸の定義，線種の定義は図 12 と同様である. 振幅の最大值は図 14(a)の風速 $U=1.60 \mathrm{~m} / \mathrm{s}$ 場合 $9.17 \mathrm{~mm}$ であり, 図 14 (b) の風速 $U=1.70 \mathrm{~m} / \mathrm{s}$ の場合 $9.44 \mathrm{~mm}$ であるので, このときも渦励振振幅が最大となる風速である $U=1.60 \mathrm{~m} / \mathrm{s}$ の場合より高い風速であ る $U=1.70 \mathrm{~m} / \mathrm{s}$ の場合の方が引き込み時の共振振幅が大きいことがわかる. この傾向は実験結果と一致している.

図 12 と図 14 を比較すると, 実験結果と同様に加振振幅が大きい図 14 の方が引き込み領域が広いことがわかる. また，共振振幅は加振振幅が 2 倍以上になっても 2 倍には達していないこともわかる.

表 1 に渦励振と強制変位加振の両方が作用した時の各風速（渦励振振幅が最大となる実験時風速 $U=1.55 \mathrm{~m} / \mathrm{s}$ と数值計算時風速 $U=1.60 \mathrm{~m} / \mathrm{s}$, および風速 $U=1.70 \mathrm{~m} / \mathrm{s}$ ) における共振振幅 $A_{V F m a x}$ を加振振幅が $0.03 \mathrm{~mm}$ と加振振幅が $0.07 \mathrm{~mm}$ の場合についてまとめている. また, それら風速における渦励振振幅 $A_{V \max }, A_{V}$ の值, 強 制変位加振のみ行ったときの共振振幅 $A_{F \max }$, およびそれらの和の值 $A_{V \max }+A_{F \max }, A_{V}+A_{F \max }$ も表中に示している. また，実験結果と数值計算結果を並べて示している，表に示した值に関して以下考察する.

まず, 渦励振と強制変位加振の両方が作用した時の共振振幅 $A_{V F \max }$ の值を実験結果と数值計算結果で比較する と, 全ての場合において数值計算結果の方が振幅が大きい，この理由は以下のように考えられる. すなわち, 強 制変位加振も同時に行うと円筒の振幅が大きくなるが，その時の渦の挙動が振幅が小さい時と異なり，円筒に作 用寸る揚力の変動量が円筒の振幅が小さい時よりも小さくなるからと考えられる.このことは実験から明らかに なっている（田中, 高原, 1970) (鉒口他, 1972) (松本他, 2008). しかしながら, 本研究の数值計算では, Iwan の渦励振モデルのパラメータ值に関して, 振幅が小さい渦励振のみの時の值を強制振動により振幅が大きくなっ てもそのまま用いているため, 実験で確認されている振幅が大きい時の揚力変動の減少効果が考慮されていない ためと考えられる.

次に, 強制自励時の共振振幅 $A_{V F \text { max }}$ を渦励振のみの時の振幅 $A_{V \max }, A_{V}$ と強制加振のみの時の共振振幅 $A_{F \text { max }}$ の 和の值 $A_{V \max }+A_{F \max }, A_{V}+A_{F \max }$ と比較してみる. 構造物の設計における簡便さの観点から, 強制自励時の共振振幅 が振動形態をこのように単純に分離した時の振幅とどのような関係にあるか調べることは重要と思われる. 風速 $U=1.70 \mathrm{~m} / \mathrm{s}$ の時は前述の $A_{V}$ が小さいが $A_{V F \max }$ が大きいという結果を受けて, 実験結果も数值計算結果も $A_{V F \max }>$ 
Yoshitake, Nagayo, Kuwazono, Yamaguchi, Inoue and Tanaka,

Transactions of the JSME (in Japanese), Vol.86, No.889 (2020)

Table 1 Summary of the maximum amplitudes of the experimental results and the numerical ones.

\begin{tabular}{|c|c|c|c|c|c|c|c|c|}
\hline & \multicolumn{4}{|c|}{$z_{0}=0.03 \mathrm{~mm}$} & \multicolumn{4}{|c|}{$z_{0}=0.07 \mathrm{~mm}$} \\
\hline$A_{V F \max }$ & \multirow{2}{*}{$\begin{array}{l}\text { Experiment } \\
U=1.55 \mathrm{~m} / \mathrm{s}\end{array}$} & $4.4 \mathrm{~mm}$ & \multirow{2}{*}{$\begin{array}{l}\text { Numerical } \\
U=1.60 \mathrm{~m} / \mathrm{s}\end{array}$} & $5.39 \mathrm{~mm}$ & \multirow{2}{*}{$\begin{array}{l}\text { Experiment } \\
U=1.55 \mathrm{~m} / \mathrm{s}\end{array}$} & $6.2 \mathrm{~mm}$ & \multirow{2}{*}{$\begin{array}{l}\text { Numerical } \\
U=1.60 \mathrm{~m} / \mathrm{s}\end{array}$} & $9.17 \mathrm{~mm}$ \\
\hline $\begin{array}{c}A_{V \max }+ \\
A_{F \max } \\
\end{array}$ & & $\begin{array}{r}2.0+2.6 \\
=4.6 \mathrm{~mm} \\
\end{array}$ & & $\begin{array}{l}2.02+2.73 \\
=4.75 \mathrm{~mm}\end{array}$ & & $\begin{array}{r}2.0+6.0 \\
=8.0 \mathrm{~mm}\end{array}$ & & $\begin{array}{l}2.02+6.36 \\
=8.38 \mathrm{~mm}\end{array}$ \\
\hline$A_{V F \max }$ & \multirow{2}{*}{$\begin{array}{l}\text { Experiment } \\
U=1.70 \mathrm{~m} / \mathrm{s}\end{array}$} & $4.5 \mathrm{~mm}$ & \multirow{2}{*}{$\begin{array}{l}\text { Numerical } \\
U=1.70 \mathrm{~m} / \mathrm{s}\end{array}$} & $5.52 \mathrm{~mm}$ & \multirow{2}{*}{$\begin{array}{l}\text { Experiment } \\
U=1.70 \mathrm{~m} / \mathrm{s}\end{array}$} & $7.3 \mathrm{~mm}$ & \multirow{2}{*}{$\begin{array}{l}\text { Numerical } \\
U=1.70 \mathrm{~m} / \mathrm{s}\end{array}$} & $9.44 \mathrm{~mm}$ \\
\hline $\begin{array}{l}A_{V}+ \\
A_{\text {Fmax }}\end{array}$ & & $\begin{array}{c}1.0+2.6 \\
=3.6 \mathrm{~mm}\end{array}$ & & $\begin{array}{l}1.18+2.73 \\
=3.91 \mathrm{~mm}\end{array}$ & & $\begin{array}{c}1.0+6.0 \\
=7.0 \mathrm{~mm}\end{array}$ & & $\begin{array}{l}1.18+6.36 \\
=7.54 \mathrm{~mm}\end{array}$ \\
\hline
\end{tabular}

$A_{V}+A_{F \max }$ となっている. 一方, 渦励振のみの時の振幅が最大になる風速（実験では $U=1.55 \mathrm{~m} / \mathrm{s}$, 数值計算では $U$ $=1.60 \mathrm{~m} / \mathrm{s})$ の時は，実験結果は， $A_{V \max }$ は小さくなく $A_{V F \max }$ がそれほど大きくないということから逆に $A_{V F \max }<A_{V \max }+A_{F \max }$ となっているが, 数值計算結果は前述の理由で $A_{V F \max }$ の值が実験值よりも大きいので $A_{V F \max }>A_{V \max }+A_{F \max }$ となっているのであり, 実験結果の $A_{V F \max }<A_{V \max }+A_{F \max }$ の方を信頼すべきと考える.

調べた風速の範囲では，このように引き込み振動時の最大振幅は，渦励振のみの時の最大振幅と強制変位加振 のみの時の最大振幅の和内外の值となったが，風速が高速側では引き込み振動時の最大振幅は各振幅の和よりも 大きな值となるので，注意が必要である．これらの結果は実構造物の設計における 1 つの目安にできると思われ るが，風速による引き込み現象の違いについては，今後さらに詳細な実験と数值計算により検証することが必要 と思われる。

\section{5. 結 言}

渦励振により自励振動を行っている系を強制変位加振するときの振動現象について実験と数值解析から調べた 結果は以下のようにまとめられる.

（1）固有振動数が含まれる加振振動数のある領域において，引き込み現象を確認した.

（2）渦励振のみのときの振幅が最大となる風速時より少し高い風速の時の方が強制変位加振時の引き込み領域 が広い場合がある。

（3）引き込み振動時の共振振幅についても同様に，渦励振のみのときの振幅が最大となる風速時より少し高い 風速の時の方が大きい場合がある.

(4)引き込み振動時の最大振幅は, 渦励振のみの時の最大振幅と強制変位加振の夕一時の最大振幅の和内外の值 となる。

（5）上記の内容について実験結果と数值解析結果はほぼ定性的に一致した.

\section{謝 辞}

最後に, 実験の協力を頂いた元長崎大学学生の中上麻里氏[現 : ダイハツ工業(株)], 志村鴻氏[現:スズキ(株)], 梅枝祐奈氏[現：長崎市役所]の諸氏に謝意を表す.

\section{文献}

赤木久眞, 中野時衛, 土肥博, 吉田献一, 巨大地震に伴う長周期地震動の特性と超高層ビルに及ぼす影響, 日本 応用数理学会論文誌, Vol.22, No.4(2012), pp.22-29.

Atluri, S., Rao, V.K. and Dalton, C., A numerical investigation of the near-wake structure in the variable frequency forced oscillation of a circular cylinder, Vol.25(2009), pp.229-244.

古村孝志, 武村俊介, 早川俊彦, 2007 年新潟県中越沖地震(M6.8)による首都圈の長周期地震動, 地学雑誌, Vol.116,

No.3 (2007), pp.576-587.

Hayashi, C., Nonlinear oscillations in physical systems, McGraw-Hill(1964), pp.283-338.

本間真, 薄達哉, 花田淳也, 前田潤滋, 鉄塔支持型煙突の渦励振に対する評価方法について, 風工学シンポジウ 
ム論文集，Vol.19(2006), pp.465-470.

飯吉亮太, 上條将広, 山田 修一, 小出瑞康, 高橋勉, 白樫正高, 周期的外力印加による渦励振特性の解明, 日本

機械学会北陸信越支部 第 49 期総会・講演会 講演論文集(2012), 講演番号 0305 .

Iwan,W.D. and Blevins,R.D., A model for vortex induced oscillation of structures, Transactions of the ASME, Journal of

Applied Mechanics, Vol.41, No.3(1974), pp.581-5856.

梶原秀一, 橋本幸男, 土屋武士, 周期入力による振子の運動制御, 日本機械学会論文集 C編, Vol.67, No.663(2001), pp.3454-3460.

松本勝, 八木知己, 橋本三智雄, 中瀬友之, 前田耕治, 構造基本断面の渦励振とギャロッピングに及ぼすカルマン 渦の影響, 第 20 回 風工学シンポジウム論文集(2008), pp.62-67.

嶺脇重雄，濱口弘樹，木下貴博，西村章，二木秀也，竹内貞光，長周期地震動を受ける超高層免震建物における

衝突緩衝材による応答低減効果に関寸る検討，日本建築学会技術報告集，Vol.23，No.55(2017)，pp.809-814. 三菱地所，横浜ランドマークタワー，影国社（1994）。

中井幹雄, 秋山悟, 円板に周期的外力が作用した場合の鳴きについて, 日本機械学会論文集 C 編, Vol.59, No.563(1993), pp.2098-2106.

NEDO（新エネルギー・産業技術総合開発機構）, 浮体式洋上風力発電技術ガイドブック (2018), pp.34-38.

大塚淳一, 田村保, 玉木利裕, 八木一浩, 洋上風力発電施設の振動計測, 土木学会第 59 回年次学術講演会,

No.6-243(2004), pp.485-486.

岡島厚，振動するブラフな物体周りの渦流れと流力特性，日本機械学会論文集 B 編, Vol.66, No.644(2000), pp. 948-953.

佐々木茅乃, 永野正行, 堀愛里香, 野津厚, 川辺秀憲, 2011 年東北地方太平洋沖地震の震源モデルを用いた関東 平野における長周期地震動評価，日本建築学会技術報告集，Vo.24，No.56(2018), pp.75-80.

Shaw, J. and Shaw, S.W., Non-linear resonance of an unbalanced rotating shaft with internal damping, Journal of Sound and Vibration, Vol.147, No.3(1991), pp.435-451.

田中博喜，高原茂，振動円柱の非定常空気力に関寸る研究，三菱重工技報，Vol.7， No.2(1970), pp.123-131.

鉒口展宏, 坂田弘, 田中博喜, 円柱構造物の風による振動，三菱重工技報，Vol.9， No.6(1972), pp.761-766.

Williamson, C.H.K. and Roshko, A., Vortex formation in the wake of an oscillating cylinder, Journal of Fluids and Structures, Vol.2(1988), pp.355-381.

山崎真司，横浜ランドマークタワーの構造設計，溶接学会誌，Vol.61， No.2(1992), pp.107-112.

吉武裕，井上順吉，末岡淳男，時間遅れをともなう強制自励系の振動，日本機械学会論文集 C 編，Vol.49, No.439(1983), pp.298-306.

吉武裕, 末岡淳男, 田村英之, 庄司長史, 不連続な非線形性をもつ系の振動(乾燥摩擦を伴う強制自励系の場合), 日本機械学会論文集 C編, Vol. 61, No. 583(1995),pp. 768-774.

吉武裕，原田晃，隠崎雅浩，山崎正則，杉村泰司，大石哲史，スロット発電機と水平振り子からなる動吸振器型 制振発電装置の研究 (第 1 報, 渦励振の制振), 日本機械学会論文集 C 編, Vol.72, No.723 (2006), pp.3467-3473.

\section{References}

Akagi, H., Nakano, T., Dohi, H. and Yoshida, K., Characteristics of long-period ground motions associated with huge earthquakes and their effects on skyscrapers, The Japan society for industrial and applied mathematics, Vol.22, No.4(2012), pp.22-29(in Japanese).

Atluri, S., Rao, V.K. and Dalton, C., A numerical investigation of the near-wake structure in the variable frequency forced oscillation of a circular cylinder, Journal of Fluids and Structures,Vol.25(2009), pp.229-244.

Furumura, T., Takemura, S. and Hayakawa, T., Long-period ground motions recorded in the Tokyo metropolitan area during the 16 July, 2007 M6.8 Off Niigata-ken Chuetsu, Japan Earthquake, Journal of Geography Vol.116, No.3/4(2007), pp.576-587(in Japanese).

Hayashi, C., Nonlinear oscillations in physical systems, McGraw-Hill(1964), pp.283-338.

Homma, S., Susuki, T., Hanada, N. and Maeda, J., Evaluation for the vortex-induced vibration of a tower supported steel 
stack, Proceedings of National Symposium on Wind Engineering, Vol.19(2006), pp.465-470 (in Japanese) .

Iiyoshi, R., Kamijyo, M., Yamada, Y., Koide, M., Thakahashi, T. and Shirakashi, M., Characteristic of vortex induced vibrations by applying a periodic external force, The Japan Society of Mechanical Engineers, Hokuriku branch general assembly and conference(2012), Lecture number 0305(in Japanese).

Iwan,W.D. and Blevins,R.D., A model for vortex induced oscillation of structures, Transactions of the ASME, Journal of Applied Mechanics, Vol.41, No.3(1974), pp.581-5856.

Kajiwara, H., Hashimoto, Y. and Tsuchiya, T., Motion control of a pendulum via periodic input, Transactions of the Japan Society of Mechanical Engineers, Series C, Vol.67, No.663(2001), pp.3454-3460(in Japanese).

Matsumoto, M., Yagi, T., Hashimoto, M., Nakase, T. and Maeta, K., Role of Karman vortex shedding on vortex-induced vibration and galloping of bluff bodies, 20th National Symposium on Wind Engineering Proceedings(2008), pp.62-67(in Japanese).

Minewaki, S., Hamaguchi, H., Kinoshita, T., Nishimura, A., Futatsugi, S. and Takeuchi, S., A study on effect of cushions installed in a seismically isolated high-rise structure under long-period ground motions, Architectural Institute of Japan, Journal of Technology and Design, Vol.23, No.55(2017), pp.809-814(in Japanese).

Mitsubishi Estate, Yokohama land mark tower, Syoukokusya(1994)(in Japanese).

Nakai, M. and Akiyama, S., Squeal of disc subjected to periodic excitation, Transactions of the Japan Society of Mechanical Engineers, Series C, Vol.59, No.563(1993), pp.2098-2106(in Japanese).

NEDO (New Energy and Industrial Technology Development Organization), Floating offshore wind power generation technology guidebook(2018), pp.34-38(in Japanese).

Ohotsuka, J., Tamura, Y., Tamaki, T. and Yagi, K., Vibration measurement of offshore wind power generation facilities, The Japan Society of Civil Engineers 59th Annual Japan Society of Civil Engineers 59th Annual Conference, No. 6-243(2004), pp.485-486(in Japanese).

Okajima, A., Vortical flow and fluiddynamic characteristics of an oscillating bluff body, Transactions of the Japan Society of Mechanical Engineers, Series B, Vol. 66, No. 644(2000), pp. 948-953(in Japanese).

Sasaki, K., Nagana, M., Hori, A., Nozu, A. and Kawabe, H., Evaluation of long-period ground motions in Kanto plain using source models for the 2011 Tohoku earthquake, Architectural Institute of Japan, Journal of Technology and Design, Vol.24, No.56(2018), pp.75-80(in Japanese).

Shaw, J. and Shaw, S.W., Non-linear resonance of an unbalanced rotating shaft with internal damping, Journal of Sound and Vibration, Vol.147, No.3(1991), pp.435-451.

Tanaka, H. and Takahara, S., Vibration of cylindrical structure induced by wind, Mitsubishi Heavy Industries technical report, Vol.7, No.2(1970), pp.123-131(in Japanese).

Ukeguchi, N., Sakata, H. and Tanaka, H., Vibration of cylindrical structure induced by wind, Mitsubishi Heavy Industries technical report, Vol.9, No.6(1972), pp.761-766(in Japanese).

Williamson, C.H.K. and Roshko, A., Vortex formation in the wake of an oscillating cylinder, Journal of Fluids and Structures, Vol.2(1988), pp.355-381.

Yamasaki, S., Structural design of landmark tower in Yokohama, Journal of the Japan Welding Society, Vol.61, No.2(1992), pp.107-112 (in Japanese) .

Yoshitake, Y., Inoue, J. and Sueoka, A., Forced self-excited vibration with time lag, Transactions of the Japan Society of Mechanical Engineers, Series C, Vol.49, No.439(1983), pp.298-306(in Japanese).

Yoshitake, Y., Sueoka, A., Tamura, H. and Shoji, O., Vibrations of nonlinear systems with discontinuities(Case of forced self-excited vibration accompanied by dry friction), Transactions of the Japan Society of Mechanical Engineers, Series C, Vol. 61, No. 583(1995), pp. 768-774(in Japanese).

Yoshitake, Y., Harada, A., Kakurezaki, M., Yamasaki, M., Sugimura Y. and Ohishi, T., Vibration quenching and electricity generation by dynamic absorber composed of generator with two slots and horizontal pendulum (1st Report, Quenching of vortex-induced vibration), Transactions of the Japan Society of Mechanical Engineers, Series C, Vol. 72, No.723(2006), pp.3467-3473(in Japanese). 